Safeer, A, A., He, Y., Abrar, M., \& Ullah, A. (2019). Diagnostics of the Challenges and Potential Solutions to Improve Export Competitiveness in International Markets: The Case of Pakistani Readymade Garments Industry. Journal of Competitiveness, 11(3), 128-143. https://doi.org/10.7441/joc.2019.03.08

\title{
DIAGNOSTICS OF THE CHALLENGES AND POTENTIAL SOLUTIONS TO IMPROVE EXPORT COMPETITIVENESS IN INTERNATIONAL MARKETS: THE CASE OF PAKISTANI READYMADE GARMENTS INDUSTRY
}

\section{- Asif Ali Safeer, Yuanqiong He, Mubammad Abrar, Atta Ullah}

\begin{abstract}
This research study has highlighted the key challenges of export competitiveness and puts forth viable solutions for improvements in the readymade garments (RMG) industry to improve market share internationally. Pakistan is a developing country, therefore, defining industry challenges and their possible resolutions have become a very important topic in the business environment of the nation. This article presents the results of a qualitative research study, with primary data collected through an open-ended questionnaire as well as with the interviews of 134 middle and senior marketing managers with 5 to 18 years' experience. The respondents come from readymade garments production units located in Faisalabad, Pakistan. Porter's Diamond theory was used with this research study to seek ways of gaining competitive advantages and improving export competitiveness in international markets. With focusing on the factor of conditions (basic and specialized resources), it is identified 100 percent of the responses highlighted the energy crisis as a severe challenge along with the other issues. As for demand conditions, 44 percent of responses highlighted the lack of their own brands. In firm strategy, structure and rivalry, 78 percent of responses identified that the international competition is a great challenge. In related and supporting industries, 70 percent of responses highlighted the lack of innovation, and 90 percent of responses agreed that government policies were key. This study has also sought to provide a number of resolutions to these issues, e.g. the government should develop employee training and development centres, research and development institutes, along with collaboration with financial institutions to obtain funding. This research study has important theoretical and practical implications for several types of industry managers, associations, as well as research and development institutions.
\end{abstract}

Keywords: RMG industry, exports, challenges, competitiveness, international markets JEL Classification: L67, M16, M31

Received: April, 2019

1st Revision: July, 2019

Accepted: August, 2019 


\section{INTRODUCTION}

The textile and garment sector plays a very important role in Pakistan's economy. It is one of the largest sectors in Pakistan, comprising 46 percent of total manufacturing and 67 percent of exports The sector employs 40 percent of the country's labor force and contributes 10.20 percent to the gross domestic product. Pakistan has also become one of the 4th biggest cotton crop producers in the world, which has fostered a strong yarn spinning and weaving industry, however unfortunately Pakistan has very low exports in international markets. Among the major reasons for the country's minimal exports are low-value addition, its unskilled and semi-skilled labor force, quality issues, management vision, as well as the lack of modern machinery. In the textile value chain, garments manufacturing is a growing sub-sector which plays an important role in overall economic growth. Nevertheless, Pakistan has an enormous potential for garments exports, especially considering relatively recent changes and emerging trends in international markets. Still, to become competitive in global markets, Pakistan's garments sector needs to develop efficient production systems and to more greatly reduce production costs to attract long term customers overseas (Garment Industry of Pakistan, 2017).

The production and distribution of readymade garments has become a very important industry in Pakistan, an industry which uses raw materials produced mainly by local suppliers. The production of Pakistani readymade exports has increased from 22.708 to 25.621 million units dozens of various sorts of readymade garments worth USD 1695.557 million in Jul-Feb FY 2018 as compared to USD 1499.472 million in Jul-Feb FY 2017, i.e. a positive trend of 12.83 percent in terms of quantity and 13.08 percent in terms of value (Economic Survey of Pakistan, 2017-18). In the "post-9/11-post-textile quotas world," Pakistan is generally not considered a favorable trading partner for global customers. Consequently, large garments manufacturing firms in Pakistan have been dealing with a situation of less business volume in international markets.

Competitiveness has been broadly studied across the world, however as of yet no comprehensive research study has been conducted on the textile sector of Pakistan in terms of competition at the cluster level of the industry (Khan et al., 2017). Despite being rich in cotton resources, relatively recent export trends of Pakistan have shown that the nation remains at an extremely low point, with less than 1 percent global market share (Safeer et al., 2018). Further, Pakistan's overall share in apparel and textiles exports is declining as a result of its weak competitiveness in overseas markets (Khan \& Abasyn, 2017). Currently, Pakistan is facing hard competition from the main giants of the region, i.e. other Asian countries such as India, China, Bangladesh, Malaysia, Thailand, and South Korea have established commendable export market shares internationally (Irshad \& Xin, 2017). In table 1 below, the world-wide export data of knitwear (hosiery) garments are shown for the years 2016-18:

Tab. 1 - Export of Knitwear (Hosiery) Garments by country. Source: Trade Development Authority of Pakistan, taken from Memon, N. A. (2019)

\begin{tabular}{|l|l|l|}
\hline \multirow{2}{*}{ Country } & $2016-17$ & $2017-18$ \\
\cline { 2 - 3 } & (Value in \$000) & (Value in \$000) \\
\hline United States & 876,104 & 963,797 \\
\hline
\end{tabular}




\begin{tabular}{|l|l|l|}
\hline United Kingdom & 367,877 & 427,183 \\
\hline Germany & 181,868 & 218,824 \\
\hline Spain & 181,745 & 202,811 \\
\hline Netherlands & 143,725 & 197,378 \\
\hline United Arab Emirates & 38,193 & 65,945 \\
\hline Canada & 35,579 & 50,280 \\
\hline Italy & 51,919 & 68,057 \\
\hline Yemen & 1,157 & 1,024 \\
\hline Belgium & 145,423 & 147,808 \\
\hline France & 63,257 & 65,986 \\
\hline Denmark & 20,634 & 21,875 \\
\hline Australia & 16,577 & 21,983 \\
\hline Japan & 15,035 & 20,888 \\
\hline China & 17,623 & 25,136 \\
\hline Russia & 15,155 & 13,584 \\
\hline Mexico & 15,523 & 12,702 \\
\hline All others & 174,064 & 185,940 \\
\hline Total & $2,361,458$ & $2,711,201$ \\
\hline
\end{tabular}

The garments sector is a very important value-added segment in the whole value chain of textiles, with international trade in the segment contributing to 53 percent of total business value, a figure which has been steadily increasing during the previous two decades.

In knitwear garments, in fiscal year 2017-18 the USA achieved a 35 percent share of total exports with a value of over USD 963 million, with approximately 32 percent going to the European Union and the remaining share of only 33 percent to the rest of the world. The United States, United Kingdom, Germany, Netherlands, Belgium, Spain, France, Canada, and Italy are the main garments business partners for Pakistan (Memon, 2019). The EU and the USA continue to be largest markets for fashion garments as well as many other garments, with a 73 percent joint share of the total global clothing business (Memon, 2017). In Pakistan, production units for garments and related accessories are located mainly in Karachi, Sialkot, Faisalabad, and Lahore, with each cluster specializing in its own aspect of garments production. All these clusters export readymade garments to different Far East, European and US markets according to each customer's requirements. However, exported readymade garments from Pakistan are of poor quality as compared to products from Sri-Lanka, India, Hong Kong, Korea, Philippines, and Taiwan. In this sector, it is required to invest a great deal of resources and to foster significant innovation to become strongly competitive in international markets (Shah et al., 2014). Factors comprising the competitiveness rank of Pakistan's garment industry are quite discouraging relative to developed economies and to other emerging world markets, a situation which has led to poor exports internationally (Zia, 2007). The global competitiveness index ranking (2017-18) has shown a ranking for Pakistan of 115 out of 137 countries, whereas the competitiveness level of India is ranked 40, Bangladesh 99 and China 15. 
This research paper is organized as follows: first, we comprehensively introduce competitiveness studies along with the main issues involved as well as how they are explored in our study. In the next section we explain the theoretical background and conduct a supplementary literature review outlining themes relevant to our work. Third, we explain our research objective, research methodology and data collection methods. After describing the primary and secondary data we have collected, we explain the research results and engage in a discussion on this study. In the end, we conclude the research study by outlining the theoretical and practical implications, including possible directions for future research.

\section{THEORETICAL BACKGROUND}

Among experts in individual national markets around the world a rising anxiety has emerged regarding the improvement of global competitiveness, which has come to be recognized as the answer to a state's economic problems. Many government institutions regularly stress the vital importance of strong competitiveness as a fundamental goal in the development of their nation's economic development policy (Olamade, 2015). Different types of researchers from diverse fields have worked hard to develop and contribute various ideas to the emergent field of competitiveness studies. In spite of the abundance of literature, the concept of competitiveness, however, remains an elusive one (Bhawsar \& Chattopadhyay, 2015). The field has been defined and explored in many ways with various sites of emphasis. Ways of adaptation and their implications along with evaluations of accomplishments vary from country to country, industry to industry, and even firm to firm. Most competitiveness studies focus on competitive performance or on the key factors affecting results (Hossain et al., 2019). Competitiveness has become the main concern of developed and developing countries, with the Porter's Diamond Model of competitiveness broadly cited as one of the best models to raise an industry's benchmarking metrics to gain competitive advantage by effectively utilizing the relevant factors (Porter, 1990; Chobanyan \& Leigh, 2006; Grant, 1991; Stonehouse \& Snowdon, 2007; Jin \& Moon, 2006; Bhaskaran, 2011).

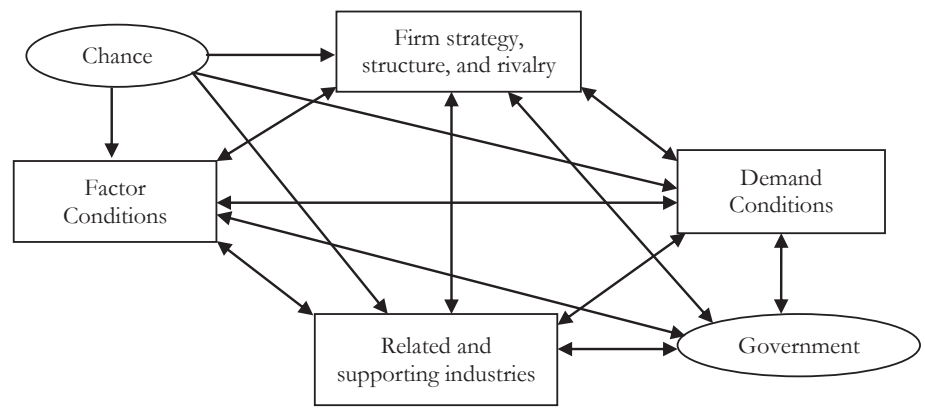

Fig. 1 - Porter's Diamond Model

Nowadays, the word "competitive advantage" is broadly used. The term "competitive advantage" was initially used by Ansoff as distinctive prospects within a firm's operations which substitutions by product market scope and growth. Porter proposed a better understanding of 
competitiveness (Aries, 2016). Competitiveness is a characteristic of markets by which a nation is capable of producing products and services in free markets terms being studied by worldwide markets while retaining and growing the real incomes and improving the lifestyle of people on a long-term basis (Ivanová \& Čepel, 2018).

Throughout the world, countries produce a total of over 17 million tonnes of knitted and apparel garments, a figure which represents one-third of the world-wide textiles market. Furthermore, the production is forecasted to grow by 25 percent in the next five years and garments production will reach more than 21 million tonnes. According to an estimate, Pakistan existing knitwear garments production is about 1.1 billion pieces of garments. From this production, 60 percent of garments production is comprised of jersey, T-shirts, knitted fabric, polo shirts, sweatshirts, tracksuits, jogging suits, and children outerwear (Memon, 2019). Pakistani textiles suppliers are generally manufacturing cotton-based textiles products like woven cloths, apparel, and knitwear garments according to international standards and the customer's requirements. This productfocused strategy not only limited Pakistan's exports but also this strategy weakened Pakistan's textile products exports earning as well (Ahmad \& Kalim, 2014). Pakistan strongly needed to work on export competitiveness challenges to get a better position in international markets.

Rahman \& Siddiqui suggested several critical factors such as reduction of China's bulk production because of labor shortages, and high paid wages also play a very vital role in the development and growth of the industry. In Pakistan, the production cost has gone, which is also one the major factors presenting the country from becoming not competitive in international markets. Many textile production units have been moved to Sri Lanka and Bangladesh just to get the lower-cost benefits (Shah et al., 2014). Pakistani readymade garments industry needed to diagnose the key challenges and solutions to cope with these challenges and to find effective solutions so that Pakistani readymade garments industry can compete in international markets. Mboya \& Kazungu (2015) also found that Porter's Diamond Model strongly supports the firm's competitive advantages and this is the best model to be set as a benchmark of firms and industries to gain the competitive edge.

Munir \& Sultan (2019) conducted a research study to analyse the export competitiveness of Pakistan with border sharing countries including China, India, Afghanistan, and Iran. They found that Pakistan has the highest comparative disadvantages on textile products exports to Afghanistan and India, while there are highest comparative advantages on textiles yarns exports to China. Pakistan has no exports on textiles yarns to Iran so Pakistan needs to improve textile products export competitiveness in all these countries. Vu \& Pham (2016) applied the Generalized Double Diamond Model to analyse Vietnam's global competitiveness in the garments and textile industry, and compared this industry with China in the context of global competitiveness. This research study results showed that Vietnam was less globally competitive in all four attributes (i.e. factor conditions, demand conditions, firm strategy, structure and rivalry, related and supporting industries) as compared to China. Kiggundu \& Uruthirapathy (2010) linked the competitiveness of Canada with its two traditional economic partners, the UK and the US, and two emerging states, India and China. The evaluation was made based on three extensive factors comprising nine pillars of competitiveness index growth (later became GCI), on domestic competition, business competitiveness and on cluster development in the years 1998 to 2006. As 
discussed before, there is lack of research on the export competitiveness challenges of the RMG industry of Pakistan so the purpose of this present research study is to bridge this gap.

\section{RESEARCH OBJECTIVE, METHODOLOGY AND DATA}

The purpose of this research study is to diagnose the challenges and solutions for the RMG industry of Pakistan. This research study also discusses the upcoming opportunities for the RMG industry of Pakistan. To conclude this research work effectively, the qualitative research was applied to diagnose the key challenges confronted by the RMG industry of Pakistan.

The qualitative research is an exploratory research and unstructured methodology based on the small samples proposed to deliver insights and understanding of the research problem situation (Malhotra \& Dash, 2010). In a qualitative research method, primary data were collected through an open-ended questionnaire with the interviews of 134 middle and senior managers of marketing having 5 to 18 years' experience in the readymade garments production units located in Faisalabad, Pakistan. As Faisalabad is the third most populous city of Pakistan, it is also called Manchester of Pakistan. The textile industry of Faisalabad is the largest industry of Pakistan where all textile sectors are working on massive scales. Faisalabad is also a very important cluster of garments manufacturing units. Interviews took about 30 - 45 minutes with each manager. This research study used the random and particularly purposive sampling technique to collect the primary data from real and valid respondents of the RMG industry.

In this research study, there were 175 experienced middle and senior marketing managers of different garments production units interviewed. These units operate with different production volumes from small (with less than 1000 Million Pak rupee business volume), medium (with business volume between 1000-2000 Million Pak rupee) to large scale (with more than 2000 Million Pak rupee business volume) levels for readymade garments production manufacturing firms in Faisalabad. After fieldwork, finally, we collected data from 134 valid respondents of 25 renowned garments production firms small, medium and large - operating in Faisalabad - Pakistan and got the average response rate of 76.57 percent to find out the major issues related to readymade garments industry. Secondary data were also used to conclude this research study. Khan \& Abasyn (2017) conducted a research study on the challenges and opportunities for small and medium enterprises in the apparel garments sector of Pakistan. To conclude that research study by using purposive sampling, they conducted semi-structured in-depth interviews with senior managers in 6 firms from 2 apparel garment clusters of Lahore, Faisalabad, and Karachi. Sharma \& Kharub (2015) conducted qualitative and quantitative research on "evaluation of barriers hindering the growth of MSMEs", in which they circulated total of 150 questionnaires and collected 67 questionnaires which were found correct so the response rate was 44.67 percent, and they recorded 42 interviews responses. The authors believed that this is a sufficient number of responses for further research analysis.

\section{RESULTS AND DISCUSSION}

This research study completed through primary data collection from experienced middle and senior managers marketing and also secondary data applied to the RMG industry. Based on the primary data collection, respondents highlighted key challenges for the readymade garments industry of Pakistan (see below). 
Tab. 2 - Key Challenges of Export Competitiveness of RMG Industry of Pakistan

\begin{tabular}{|c|c|c|c|c|}
\hline \multirow{2}{*}{$\begin{array}{l}\text { Porter's } \\
\text { Model Fac- } \\
\text { tors }\end{array}$} & \multirow{2}{*}{$\begin{array}{l}\text { Key Challenges of Export Com- } \\
\text { petitiveness }\end{array}$} & \multicolumn{3}{|c|}{ Response on Challenges } \\
\hline & & Sample Base & $\begin{array}{l}\text { Number of } \\
\text { Responses }\end{array}$ & $\%$ \\
\hline FC & Increasing Raw Material Prices & 134 & 95 & $71 \%$ \\
\hline FC & Labor Productivity & 134 & 79 & $59 \%$ \\
\hline FC & Energy Crisis & 134 & 134 & $100 \%$ \\
\hline FC & Lack of Investment & 134 & 77 & $57 \%$ \\
\hline DC & Lack of Own Brands & 134 & 59 & $44 \%$ \\
\hline FSSR & International Competition & 134 & 105 & $78 \%$ \\
\hline RSI & Lack of R\&D Institutions & 134 & 63 & $47 \%$ \\
\hline RSI & Poor Supply Chain Management & 134 & 50 & $37 \%$ \\
\hline RSI & Lack of Innovation & 134 & 94 & $70 \%$ \\
\hline RG & Law and Order Situation & 134 & 118 & $88 \%$ \\
\hline RG & Government Policies & 134 & 120 & $90 \%$ \\
\hline
\end{tabular}

Source: Own research $(\mathrm{FC}=$ Factor Conditions, $\mathrm{DC}=$ Demand Conditions, FSSR $=$ Firm Strategy, Structure and Rivalry, RSI = Related and Supporting Industries, RG = Roles of Government)

According to the primary data collection and response rate from respondents, in factor conditions, energy crises was the worst challenge faced by the readymade garments industry. The score of energy crises was 100 percent. Electricity is the key challenge for the garments industry. Due to electricity shutdowns, readymade garments industry production suffered a lot and, ultimately, shipments are delayed, and also the cost of production is increasing due to alternative energy sources utilization. Delays in shipments caused the reputation problem of Pakistani suppliers. In the same way, gas energy also plays an important role in the garments production process. Gas energy is mostly used to generate the steam in dying machines for the processing of garments and gas energy is also used for boilers. Due to non-availability of gas energy for the industry, many production units had closed and got unemployed in the country. Shah et al. (2012) suggested that the overall textile sector of Pakistan has serious concerns regarding electricity and gas load shedding. Awan et al. (2019) also mentioned that Pakistan was facing severe energy shortages over the previous few years. The main reason for these unexpected power outages is the usage of resources. Furthermore, energy blend for the generation of electricity and the resulting circular debt problem is also worsening of the situation.

In factor conditions, the second important issue was highlighted - the increasing prices of raw material with a score of 71 percent. The main reason of increasing raw material prices is that the cotton ginners are getting extraordinary cotton prices from spinners while this benefit is not passing on to the cotton growers. Just because of that reason, many farmers are not growing cotton with huge volume and eventually, the prices of cotton are increasing, and this increase in price influenced the garment industry badly. Due to cotton, the prices of yarn are also increasing and this creates the competitiveness issue for the industry. Other materials such as packaging prices and accessories prices are also increasing. In this situation, the government should pay attention to resolve the industry problems, so that garments manufacturers can compete in the 
world markets since the cost of products is majorly dependent on the prices of raw materials.

In factor conditions, the third important issue was highlighted - the productivity of the labor force with a score of 59 percent. It does not mean that low wages always provide competitive advantages when labor productivity is low and poor. Poor labor productivity is one of the key challenges for the competitiveness of readymade garments industry, because productivity may be one of the criteria improving business competitiveness. Increasing job opportunities might be a sign of increasing business competitiveness only if its basis is the development of labor productivity, application of new technologies and production techniques (Sergej, 2016).

In factor conditions, the fourth important challenge - the lack of investment was highlighted, with a score of 57 percent. Lack of investment is a great challenge for the readymade garments industry. Many companies are unable to promote their business and even many production units had been closed due to lack of investments in Pakistan. Due to lack of investment, most firms have lack of modern machinery. The incapability of timely improvement in machinery had also caused weaking the competitiveness of Pakistani textile products. Due to outdated technology, the cost of production is much higher in Pakistan compared to China, India, and Bangladesh (Khan \& Khan, 2010). Old machinery consumes more energy and labor with a low output which is big hurdle for becoming competitive in the local and external markets. As for the present situation of Pakistan, people and other institutions are not very much convinced the need of investing in the textile sector. The sources of foreign investments, access to foreign markets, and international knowledge links are important components to the development and growth projections of developing countries (Tvaronaviciene\& Razminiene, 2017). Although foreign direct investment trend has been positive in the last three years in Pakistan, the government should focus on the garment sector to improve the investment with better business prospects and opportunities. The foreign investment trends in Pakistan from 2010-2018 were as follows:

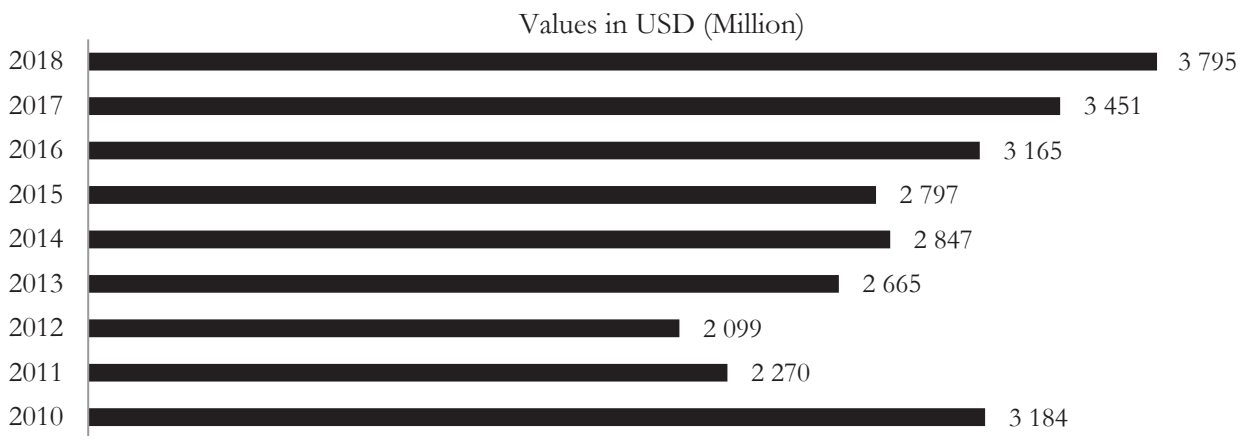

Fig. 2 - Foreign Direct Investment in Pakistan (2010-2018). Source: State Bank of Pakistan (2018)

Factor conditions include basic and advanced factors. Basic factors are raw material, unskilled labor, and climate conditions, etc. which require no investment or low investment in the production process. Nowadays, the Pakistani garments industry is facing the challenges of high raw material costs, low labor productivity, and lack of basic facilities such as electricity and gas energy for production processes. Advanced factors are developed through innovation and investment 
to facilitate the production process. In this regard, the Pakistani garments industry is facing the problem of lack of investment to create specialized resources.

Demand conditions are very important in any industry as the domestic demand leads to the international one. If the domestic demand is high, firms will increase investment and achieve economies of scale which will help to gain competitive advantages. In the countries where local buyers have sophisticated demands, the firms are required to upgrade and achieve high standards to respond to the strong challenges (Kharub \& Sharma, 2017). In demand conditions, another highlighted challenge was the lack of own brands in the global markets. The lack of own brands score reached 44 percent. Pakistani firms normally manufacture international big brands, and they export these branded garments to international customers according to their requirements. Pakistani garment firms do not have their own and well-reputed brands. Pakistani firms are fully dependent on a foreign brands production. Pakistani garments manufacturers should also focus on domestic demands because Pakistan is 6th most populous country in the world and there is huge domestic demand for all types of garments. So, local demand can help to make innovation, which can lead to higher international demand.

Firm strategy, structure, and rivalry are also the most critical factors because the local as well as international competition can to enhance the firm's competitiveness, improve the innovation and quality level. In firm strategy, structure and rivalry a very important challenge was highlighted as international competition with the score of 78 percent. 105 respondents believed that international competition is a great challenge for the RMG industry. International competitors such as India, China, Bangladesh, and many other countries are always offering cheaper prices to foreign customers to win the business. International competition always creates hurdles to grab the business from foreign customers.

Related and supporting industry identified as external factors, such as the network of institutions and suppliers who provide raw materials at competitive prices, can lead to a good source of competitive advantage for the industry. In related and supporting industry (RSI), lack of innovation with the 70 percent score was highlighted as one of the critical challenges which the RMG industry faced. Pakistani garment manufacturing companies are producing traditional garments in massive volume, there is no good product innovation on bulk volume while international customers are demanding innovated products at low cost. Many researchers also emphasize the significance of innovation for competitiveness and export performance (Dobrovic et al., 2018). The second highlighted challenge in RSI was lack of research and development institutions with a score of 47 percent. Due to tough competition in the international markets, good research and development institutions are required to develop new products and innovated products to attract foreign customers. The third highlighted challenge in RSI was poor supply chain management with a score of 37 percent. Poor supply chain management is another big challenge in order to become competitive in international markets. The supply chain is a complex network of many organizations in which movements of material, information, money, and ownership happen (Majumdar \& Sinha, 2019). The effective and efficiently organized supply chain is primarily a key source of competitive advantage for the firm. However, the effectiveness and efficiency of a supply chain completely depend on its good co-ordination and effective integration. Thus, it is essential for the firms to be well-coordinated and integrated with supply chain processes to 
achieve competitive advantages (Shujaat et al., 2019). Pakistani readymade garments production firms need to manage effective supply chain processes to get good competitive advantages in local and international markets.

The role of government is indirectly recognized and included as a characteristic of the Diamond Model, but rather as an important and influential factor through economic policy, one which can influence the competitiveness of any industry. Regarding the role of government, the key challenge was highlighted: government policies showed a 90 percent score. Variations in government policies such as the imposition of new taxes; increases in existing taxes or interest rates; and the significant imposition of duties on textile raw materials import can all cause an increase in final garment costs, which creates problems for the industry and hinders competitiveness in international markets. The government has the responsibility to improve business conditions by creating and implementing appropriate policies to safeguard the garment industry. A similar research study in India also found low results using Porter's Diamond Model in an examination of the textile sector. Despite tremendous potential in exports, the Indian textile industry is unable to fully exploit its potential due to government policies, a lack of entrepreneurship skills and limited financial resources (Kharub \& Sharma, 2017). Another key challenge highlighted was the law and order situation in Pakistan, which received an 88 percent score. The greatest challenge Pakistan faces is terrorism, the threat of which creates uncertainty as well as instability in the country. For this reason, many foreign customers are not willing to finalize business with Pakistani RMG suppliers and some companies and customers are even hesitant to visit Pakistan at all due to lawlessness and potential for violence. Terrorism also creates problems for firms by increasing their costs and also decreasing by international competitiveness purely because of the negative image of the state (Khan \& Abasyn, 2017). Although the terrorism situation is getting better in Pakistan, i.e. a 29 percent decrease was shown as compared to 2018, threats from attacks remain a problem. According to the following graphical presentation, 262 terrorist attacks were carried out by various nationalist/insurgent, militant and violent sectarian groups in Pakistan in the year 2018. In these attacks, 595 people lost their lives and 1,030 people were injured (Pakistan Security Report, 2018).

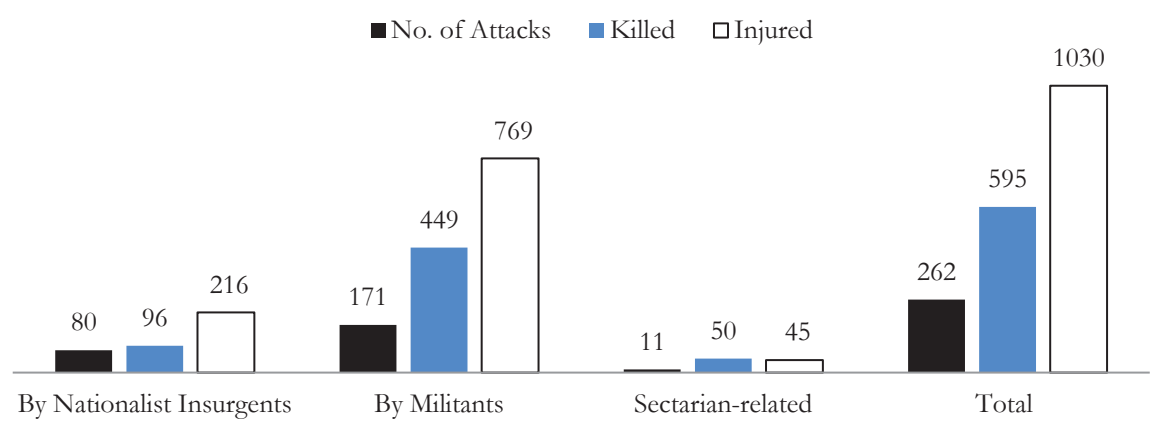

Fig. 3 - Terrorist Attacks in Pakistan for the year 2018. Source: Pakistan Security Report, 2018

Taking into account above these results, all stakeholders (including the government, industry suppliers, manufacturers, associations and consultants) should work together to cope with these 
challenges so that garment industry can become more competitive in international markets. Every stakeholder's role is critical to improve the factors of competitive advantage, e.g. the government should put forth an effort to fight the energy crisis in the industry by instituting zero percent load-shedding of electricity and gas. The government should also introduce policies beneficial for the industry to promote exports and increase foreign remittances by providing tax exemptions on raw materials, export incentives, rebates, etc. The government of Pakistan is indeed making an effort to improve the law and order situation of the state so that terrorism attacks should be close to zero percent, a condition which will also encourage foreign investors and customers to expand their business in Pakistan. If all of these measures are carried out, the garment industry will gain a competitive advantage and will prosper in international markets. Zeibote et al. (2019) have also suggested that the government should play a vital role in other aspects, e.g. the government should guarantee an adequate supply of the resources which are essential for creating a competitive advantage and development within the industry.

The garments manufacturers should focus on developing brands and introducing them both at home and abroad, as regularly featuring new brands has been shown to increase profitablity in both local and international markets. Strong brands which capitalize on domestic demand in turn leads to generating and increasing demand in international markets. Suppliers and manufacturers should work as business partners to remove the gaps in supply chain management to define practices and perspectives that can efficiently associate all the manufacturers, suppliers, distributors and customers to attain long-term objectives and performance goals (Basheer et al., 2019). Suppliers and manufacturers should work in tandem to develop raw materials prices mechanism for the stability of prices. Further, industry associations and consultants should cooperate regarding innovation, employee training and development to improve productivity. A significant number of research studies have specified the positive association between innovation and external co-operation (Shafi et al., 2019). Along with improving productivity and innovation in garment production, Pakistani manufacturers should reduce prices to compete in international markets while maintaining reasonable profits. With regard to global markets, Safeer et al. (2018) have also suggested that all garments firms should work together to effectively foster competitive advantages to secure maximum market shares for all.

\section{CONCLUSION}

This research study has attempted to contribute to the existing literature and theory with the goal of improving the export competitiveness of the RMG industry of Pakistan. Using the Diamond Model of Porter, who has presented the most used model for the competitiveness of firm, industries and entire nations, we have tried to demonstrate how the Pakistani garments industry can improve its competitiveness in international markets in specific ways. This research study has emphasized the key challenges to help the garment industry in Pakistan minimize its problems and maximize its competitiveness. A number of valuable solutions to improve the garments industry to improve and business in international markets have also been suggested. Recognizing industry challenges and forming viable solutions are of great importance in the business environment of Pakistan, a developing country. According to the research results, the export competitiveness of the Pakistani RMG industry of can be advanced in the following ways: 
- The energy crisis should be taken as a priority requiring serious solutions. With regular energy supply efficiency, production will improve and the dependability of shipment delivery systems can be improved. With this competitive advantage, RMG manufacturers can secure good business volumes in international markets.

- The government of Pakistan should develop training and development centers throughout the whole country, so that this more skilled and qualified labor force can increase the production efficiency, and thus minimize costs. This would bring a great advantage in international markets.

- The government should create conditions to improve the situation of lawlessness and violence in the country. Although the government is taking measures to completely rid Pakistan of terrorism, i.e. a decrease of attacks by 29 percent has been shown as compared to last year, a lot of work remains to be done. The government should develop a special security force to fight local crimes and terrorism. The government should assure full security to investors and foreign customers so that they can have the confidence to travel, consult and otherwise conduct business freely throughout the country.

- Research and development institutions as well as innovation centers should be established throughout the country. Innovation is considered to be the key element of competitiveness that creates growth within an economy (Mihaela, 2016). Garments production units should develop innovation strategies for all phases of the process from start to finish. Ongoing innovation enhances profitably in domestic as well as international markets.

- Garment manufacturing firms should constantly be developing and initiating new premium quality brands, which has also been shown to foster long-term gains both domestic and foreign markets.

- The government of Pakistan should review its current policies for the garments industry and should formulate new policies to become export-oriented and thus more friendly for readymade garments manufacturers. In these policies, the government should assist garment units with rebates on exports, facilitate manufacturing with long-term financing (e.g. 10 years) with low-interest rates, secure special funding for upgrading machinery with the latest technology, and, finally, the government should develop institutions which would help the garment manufacturers develop new export markets. Companies would thus become more competitive and this would also inspire the garment firms themselves to place more emphasis on exports to improve their business in foreign markets.

- The government should collaborate with financial institutions to provide adequate finances to readymade garments manufacturers. This will be helpful to expedite the production process to manage the export shipments more efficiently and reliably.

This research work should have several important theoretical and practical implications for various garment associations, research and development institutions, and consultants. This study hopes to contribute to the existing theory by highlighting the major challenges faced by the industry and also to provide effective solutions to help firms gain competitive advantages and improve their export competitiveness in international markets. 
Practically, this research study could guide industry managers, garment associations, research and development institutions as well as consultants to increase their knowledge about export competitiveness challenges as well as how to cope with them through its suggested solutions. Managers, administrators and officials can thus make effective decisions to increase export competitiveness and improve the overall course of business in overseas markets. Although primary data were collected from Faisalabad, one of the main clusters of the garment industry, the results of this research study can be generalized, since the same issues prevail throughout the whole country and general government policies can be applied in all the regions. Despite the attempts at a valuable contribution, this research study also has some shortcomings. First, the limited sample size could definitely be increased in future research to validate the results more deeply and broadly. Next, this study was limited to the RMG industry, however there are many other aspects of the RMG industry which need to be addressed in future research. Third, although this research study was limited to only one sector, i.e. the readymade garment industry, many other textile sectors could be examined such as weaving, processing, spinning, etc. can be addressed in future research studies. Finally, this study was limited to conditions in Pakistan, but the theoretical background as well as practical methodology could be extended to other countries to more greatly generalize the findings of this research.

\section{References}

1. Ahmad, N., \& Kalim, R. (2014). Implications of Export Competitiveness, and Performance of Textile and Clothing Sector of Pakistan: Pre and Post Quota Analysis. Pakistan Journal of Commerce and Social Sciences, 8 (3), 696-714.

2. Aries, P. H. (2016). What Drives International Competitiveness? An Empirical Test in Emerging Indonesian Market. Journal of Competitiveness, 8 (4). 124-139. https://doi. org/10.7441/joc.2016.04.08

3. Awan, H. S., Samad, G., \& Faraz, N. (2019). Electricity Subsidies and Welfare Analysis: The Perspective of Pakistan.

4. Basheer, M., Siam, M., Awn, A., \& Hassan, S. (2019). Exploring the role of TQM and supply chain practices for firm supply performance in the presence of information technology capabilities and supply chain technology adoption: A case of textile firms in Pakistan. Uncertain Supply Chain Management, 7 (2), 275-288. doi: 10.5267/j.uscm.2018.9.001

5. Bhaskaran, P. B. (2011). Strategic firm response to developing economy challenges. Global Business Review, 12 (1), 71-86. https://doi.org/10.1177/097215091001200105

6. Bhawsar, P., \& Chattopadhyay, U. (2015). Competitiveness: review, reflections and directions. Global Business Review, 16 (4), 665-679. https://doi.org/10.1177/0972150915581115

7. Jin, B. and Moon, H. (2006), “The diamond approach to the competitiveness of Korea's apparel industry", Journal of Fashion Marketing and Management, 10 (2), 195-208. https://doi. org/10.1108/13612020610667504

8. Chobanyan, A., \& Leigh, L. (2006). The competitive advantages of nations: Applying the "Diamond" model to Armenia. International Journal of Emerging Markets, 1 (2), 147-164. https://doi.org/10.1108/17468800610658316 
9. Dobrovic, J., Gallo, P., Mihalcova, B., Stofova, L., \& Szaryszova, P. (2018). Competitiveness Measurement in Terms of the Europe 2020 Strategy. Journal of Competitiveness, 10 (4), 21-37. https://doi.org/10.7441/joc.2018.04.02

10. Ministry of Finance. (2018). Economic Survey of Pakistan (2017-18). Retrieved on December 05, 2018 from http://www.finance.gov.pk/survey/chapters_18/03Manufacturing.pdf

11. Essays, UK. (May, 2017). The Garment Industry of Pakistan. Retrieved on November 25, 2018 from https://www.ukessays.com/essays/economics/analysing-the-garment-industryof-pakistan-business-essay.php\#citethisFinance.

12. Grant, R. M. (1991). Porter's 'Competitive advantage of nations': an assessment. Strategic management journal, 12 (7), 535-548. https://doi.org/10.1002/smj.4250120706

13. Hossain, S., Kabir, R., \& Latifee, E. H. (2019). Export Competitiveness of Bangladesh Readymade Garments Sector: Challenges and Prospects. International Journal of Research in Business and Social Science, 8 (3), 45-63. https://doi.org/10.20525/ijrbs.v8i3.205

14. Irshad, M. S., \& Xin, Q. (2017). Determinants of exports competitiveness: an empirical analysis through revealed comparative advantage of external sector of Pakistan.

15. Ivanová, E., \& Čepel, M. (2018). The impact of innovation performance on the competitiveness of the Visegrad 4 countries. Journal of Competitiveness, 10 (1), 54-72. https:// doi.org/10.7441/joc.2018.01.04

16. Khan, A. A., \& Khan, M. (2010). Pakistan textile industry facing new challenges. Research journal of international studies, 14 (14), 21-29.

17. Khan, M., \& Abasyn, J. (2017). An exploratory evidence of the types of challenges and opportunities perceived by the Small and Medium Enterprises (SMEs) in the apparel export sector of Pakistan. University Journal of Social Sciences, 10 (2), 373-395.

18. Khan, S., Murtaza, G., Jamil, R. A., \& Qadir, I. (2017). Confirmatory Analysis of the Factors of Competitiveness in the Textile Industry of Pakistan. Sarbad Journal of Management Sciences, 3 (1), 70-83. https://doi.org/https://doi.org/10.31529/sjms.v3i01.79

19. Kharub, M., \& Sharma, R. (2017). Comparative analyses of competitive advantage using Porter diamond model (the case of MSMEs in Himachal Pradesh). Competitiveness Review: An International Business Journal, 27 (2), 132-160. https://doi.org/10.1108/CR-02-2016-0007

20. Kiggundu, M.N., \& Uruthirapathy, A. (2010). Canada's global and business competitiveness: Competition policy reform in a changing world. Competitiveness Review, 20(4), 288-304. https://doi.org/10.1108/10595421011065307

21. Majumdar, A., \& Sinha, S. K. (2019). Analyzing the barriers of green textile supply chain management in Southeast Asia using interpretive structural modeling. Sustainable Production and Consumption, 17 (1), 176-187. https://doi.org/10.1016/j.spc.2018.10.005

22. Malhotra, N. K., \& Dash, S. (2010). Marketing research: An applied approach. US: Persons.

23. Mboya, J., \& Kazungu, K. (2015). Determinants of competitive advantage in the textile and apparel industry in Tanzania: The application of Porter's diamond model. British Journal of Economics, Management \& Trade, 7 (2), 128-147. https://doi.org/10.9734/BJEMT/2015/16208 
24. Memon, N. A. (2017). Readymade garment industry surviving against intense international competition. Pakistan Textile Journal, 66 (1), 42-42.

25. Memon, N. A. (2018). Readymade garment industry: Brand consciousness among people increasing every day. Pakistan Textile Journal, 67 (1), 54-54.

26. Memon, N. A. (2019). Pakistan's knitwear industry achieves new milestones. Pakistan Textile Journal, 68(1), 47-49.

27. Simionescu, M. (2016). Competitiveness and economic growth in Romanian regions. Journal of Competitiveness, 8 (4), 46-60. https://doi.org/10.7441/joc.2016.04.03

28. Munir, K., \& Sultan, M. (2019). Export competitiveness with border-sharing countries: an assessment of Pakistan. Competitiveness Review: An International Business Journal, 29 (2), 96-118. https://doi.org/10.1108/CR-08-2017-0046

29. Olamade, O. (2015). Nigeria in Global Competitiveness Comparison. Journal of Economics, 3 (2), 146-158. https://doi.org/10.15640/jeds.v3n2a15

30. Porter, M. E. (1990). The competitive advantage of nations. Competitive Intelligence Review, 1 (1), 14. https://doi.org/10.1002/cir.3880010112

31. Safeer, A. A., Abrar, M., Baig, S. A., Basit, A., Zia-Ur-Rehaman, M., \& Hashim, M. (2018). Export competitiveness analysis of Pakistan garments industry based on GEM Model. Industria Textila, 69 (3), 219-229

32. Shafi, M., Yang, Y., Khan, Z., \& Yu, A. (2019). Vertical Co-operation in Creative MicroEnterprises: A Case Study of Textile Crafts of Matiari District, Pakistan. Sustainability, 11 (3), 920. https://doi.org/10.3390/su11030920

33. Shah, S. A. S., Abidi, A. R., Chandio, F., \& Shaikh, F. M. (2014). Issues in Garments Sector in Pakistan: A Pareto Analysis. Journal of Economics, 2 (1), 233-239.

34. Shah, S. A. S., Syed, A. A. S. G., \& Shaikh, F. M. (2014). Impact of Textile Industry on Pakistan Economy. Romanian Statistical Review Supplement, 62 (3), 43-59.

35. Shah, W., Warraich, U. A., \& Kabeer, K. (2012). Challenges Faced by Textile Industry of Pakistan: Suggested Solutions. KASBIT Business Journal, 5 (1), 33-39.

36. Sharma, R. K., \& Kharub, M. (2015). Qualitative and quantitative evaluation of barriers hindering the growth of MSMEs. International Journal of Business Excellence, 8 (6), 724-747. https://doi.org/10.1504/IJBEX.2015.072307

37. Shujaat, M., Naghavi, N., \& Mubarak, F. (2019). Impact of supplier relational capital on supply chain performance in Pakistani textile industry. Asian Economic and Financial Review, 9 (3), 318-328. https://doi.org/10.18488/journal.aefr.2019.93.318.328

38. Stonehouse, G., \& Snowdon, B. (2007). Competitive advantage revisited: Michael Porter on strategy and competitiveness. Journal of Management Inquiry, 16 (3), 256-273. https://doi. org/10.1177/1056492607306333

39. Tvaronaviciene, M., \& Razminiene, K. (2017). Towards competitive regional development through clusters: approaches to their performance evaluation. Journal of Competitiveness, 9 (4), 133-147. https://doi.org/10.7441/joc.2017.04.09 
40. World Economic Forum. (2018). The Global Competitiveness Report (2017-18). from http://www3.weforum.org/docs/GCR20172018/05FullReport/TheGlobalCompetitiveness Report2017\%E2\%80\%932018.pdf

41. Vojtovič, S. (2016). The impact of the structural funds on competitiveness of small and medium-sized enterprises. Journal of Competitiveness, 8 (4), 30-45. https://doi.org/10.7441/ joc. 2016.04 .02

42. Vu, H. T., \& Pham, L. C. (2016). A dynamic approach to assess international competitiveness of Vietnam's garment and textile industry. SpringerPlus, 5 (1), 203. https:// doi.org/10.1186/s40064-016-1912-3

43. Zeibote, Z., Volkova, T., \& Todorov, K. (2019). The impact of globalization on regional development and competitiveness: cases of selected regions. Insights into Regional Development, 1 (1), 33-47. http://doi.org/10.9770/IRD.2019.1.1(3)

44. Zia, U. (2007). International Competitiveness - Where Pakistan Stands? Working Papers \& Research Reports, 2007-2028.

\section{Contact information}

Asif Ali Safeer, PhD Student, Corresponding Author

Huazhong University of Science and Technology, School of Management

1037 Luoyu Road, Hubei, Wuban, China

Email:aasafeer@outlook.com

ORCID: 0000-0001-5877-1201

Professor Yuanqiong He, PhD

Huazhong University of Science and Technology, School of Management

1037 Luoyu Road, Hubei, Wuban, China

Email:beyuanqiong@mail.hust.edu.cn

Associate Professor Muhammad Abrar, PhD

GC University Faisalabad, Lyallpur Business School

New Campus, Jhang Road, Faisalabad, Pakistan

Email:abrarphd@gmail.com

ORCD:0000-0002-1128-5350

Atta Ullah, PhD Student

Huarbong University of Science and Technology, School of Management

1037 Luoyu Road, Hubei, Wuban, China

Email:attaullab142@hotmail.com 